\title{
Conceptions on PBL Facilitator's Role: A Perspective of Chinese Teacher
}

\author{
Huichun Li \\ Research Institute for Higher Education \\ Fudan University, China \\ Yuanyuan Chen \\ School of Social Development and Public Policy \\ Fudan University, China
}

\begin{abstract}
Teachers' conceptions on their role produce significant influences upon their performance in the class and students' learning outcome. This study aims to investigate Chinese teachers' conceptions on their role as PBL (problem based learning) facilitators. A total of 32 semi-structured interviews are conducted, complementing by observations as cross-validating data source. Data analysis is carried out in a qualitative manner. The findings are: 1 The majority of the PBL teachers consider their role as either dominator or directors for students and tend to maintain strong dominance over students' learning process, 2 a few teachers take an "outsider" view by granting student high autonomy and keeping a minimum interference with student' learning process. The polarized conceptions on PBL teachers' role can be accounted partly by Chinese particular educational tradition and a lack in the knowledge regarding PBL. Therefore, to facilitate PBL implementation in China, a conceptual change to Chinese teachers regarding learning and good teacher, and more institutional support equipping teachers with PBL related knowledge and facilitating skills are needed.
\end{abstract}

Keywords: conception; facilitator's role; PBL; problem based learning; Chinese teacher.

\section{Introduction}

Since its inception in North America in the late 1960s, PBL has drawn increasing interests from researchers and practitioners worldwide and its use is spreading from medical field in Canada to many other regions and countries (e.g.: Bowe, 2007; Stojcevski \& Ozansoy, 2009; Hallinger \& Lu, 2011; Frambach et al., 2012; Li $\& \mathrm{Du}, 2015)$. In general, PBL is student-directed learning approach (De Graaff \& Kolmos, 2003; Li, 2013) which requires students to take a more active role in the 
whole teaching and learning process. Students are expected to make decisions regarding learning objective design, learning activity arrangement, conducting assessment, and so on. PBL also require teachers to shift their role from traditional instructor to facilitator (Ertmer \& Simons, 2006; De Graaff \& Kolmos, 2003; $\mathrm{Li} \& \mathrm{Du}, 2018$ ). However, the change in the role of the teacher is not an easy task, and it is especially so when western originated PBL model is introduced in higher education institutes in Asian countries such as China where the educational and cultural tradition is quite different from North America and Europe. So far, few researches have been conducted on PBL implementation in China (e.g.: Wang et al., 2008; Li, 2013; Fan et al., 2014; Du, Su \& Liu, 2013; Zhan, 2018), however, most of them place their focus on the effectiveness of PBL in enhancing student' learning quality in terms of different kinds of skill development (Frambach et al., 2014), or Chinese students' attitudes towards PBL (Huang, 2005; Du, Su \& Liu, 2013). Quite few studies set their focus on Chinese teachers' conceptions of their role within PBL context (e.g.: Li \& Du, 2015). This study aims to investigate Chinese teachers' conceptions of their role as PBL facilitator by exploring a Chinese medical institute which has implemented PBL model in recent years.

\section{State of art}

PBL receives increasing research attention in recent years. Given the aim of this study, the literature review includes the basic knowledge of PBL, teachers' role within PBL context, and in particular, PBL implementation and teachers' perceptions with regard to PBL in China.

\subsection{What is PBL}

PBL is widely regarded as an innovative educational approach or a philosophy (Savin-Baden \& Major, 2004; Barrett \& Moore, 2010) distinguishing itself in many ways from traditional teacher-dominated educational method highlighting teachers' control over teaching and learning process and the primacy of theoretical knowledge. Historically, many attempts have been made to address the meaning of PBL (De Graaff \& Kolmos , 2003; Dolmans et al., 2005; Kolmos, 2008; Li \& Du, 2018). De Graaff and Kolmos (2003) consider PBL as having several principles regarding learning, such as problem based learning, participant-directed study, experience learning, activity based learning, interdisciplinary study, exemplary practice and team work. Dolmans et al. (2005) conceive PBL as a constructive, self-directed, collaborative and contextual learning approach. Savery (2006) reviews several PBL definitions and consider the following as essential principles for PBL: students taking responsibility, problem guided learning, cross-disciplinary learning, collaboration among students, analysis and discussion on the already-gained knowledge, self and peer assessment, connecting learning activities and real word, assessing learning progress, holistic application of PBL. Li and Du (2018) compare several PBL approaches and argues that a pure PBL model should contain principles in terms of problem-centeredness, project-organized learning, authentic study, social learning, learning across different disciplines, thematic designing, and studentcenteredness. 
Albeit all different meanings of PBL, in general, PBL represents a new educational idea: knowledge should be socially constructed under the guidance of teacher though the process of dealing with authentic problem rather than the transmission of ready-made knowledge from teacher to student, therefore learning of PBL is started with the presentation of a problem situation which later directs the whole learning process (De Graaff and Kolmos, 2003; Savery, 2006; Li \& Du, 2018). Further, in contrast to traditional education context in which students are passive learners who merely follow teachers' instructions and guidance, PBL represents a student-centered learning approach which requires student to take an active role in the whole learning process (Savery, 2006). Students should have an ownership of the whole learning process and take responsibility for learning (English \& Kitsantas, 2013). They should have the right to define learning objectives, arrange learning process, and make assessment. PBL students become more involved in learning process and it is from this point that PBL shows significant strength in enhancing student learning outcome (Alrahlah, 2016). It also points to the transformation of the role of the teacher from traditional instructor to facilitator (Barrows \& Tamblyn, 1980; De Graaff \& Kolmos, 2003; Li \& Du, 2018).

\subsection{Teachers' role within PBL context}

Since teachers' conceptions of their role produce significant influence upon how they perform in the class (Dolmans, Gijselaers, Moust, et al., 2002) and students' learning interest and learning outcome(Chan, 2008; Rotgans \& Schmidt, 2011), many attempts have been made to address teachers' role in PBL context (SavinBaden, 2003; Ertmer \& Simons, 2006; Connolly \& Silen, 2011; Li \& Du, 2015). As PBL is widely conceived as a student-centered learning approach (Savery, 2006) which means PBL should be student directed, participant-directed, PBL teachers should change their role from traditional instructors to facilitators (Boud, 1985; Savery, 2006).

Generally speaking, good facilitators are not to control students and their learning process; rather, they should offer adequate and appropriate academic and infrastructure support to students (Savin-Baden, 2003). The support could take various forms in terms of lectures, tutoring, consultation, instruction, academic resource, and so on. As facilitators, teachers should give students learning autonomy ( $\mathrm{Li} \& \mathrm{Du}, 2015)$ so that students are able to learn to take responsibility of their learning. An experienced PBL teacher should have a basic knowledge of the tutorial and be able to manage students' learning process (Chan, 2008). They should iterate PBL principles, divide responsibility among students properly, establish discussion forum and create active learning atmosphere (Lee, Lin \&Lin, 2012). In order to do so, Yew and Yong (2014) suggest that PBL teachers should understand students' perspectives in order to become good facilitators. Good facilitators should have a "suitable knowledge base regarding the topic under study, a willingness to become involved with students in an authentic way, and the skill to express oneself in a language understood by students" (Schmidt \& Moust, 2000: 47). 
In addition to the basic agreement on PBL facilitator, there are many studies on the categorization of PBL teachers' different roles. For instance, Dahlgren, Castensson and Dahlgren (1998) note two different views on the PBL teachers' role through an empirical analysis: a supportive PBL teacher, who focuses on the group process and the students' learning activities, and a directive PBL teacher, who concerns more on his/her influence on teaching method and student. It is also found that the role of teacher as directive PBL facilitator could be either restricted or uncertain. Mohamad et al. (2009) generalizes three categories of facilitators, the ones actively involving in the tutorial process, the ones dominating students and allowing no learning autonomy to students, and the ones acting passively and offering students little guidance. Compared with the categories developed by Dahlgren, Castensson and Dahlgren (1998), these three categories represent three different perspectives, a teacher-centered one, a student-centered one, and an in-between one. Donnelly (2013) discovers the complexity of PBL teacher's role and Lyberg-Åhlander, Lundskog and Hansson (2014) state that PBL facilitator should keep a balance among requirements from different sources.

There are still theoretical disputes on issues such as what could be counted as good PBL facilitators and how they develop. For instance, though PBL shifts the focus from teacher to student, Mascolo (2009) argues that positioning a PBL teacher as a facilitator is somehow weakening the function of the teacher and thus detrimental for student learning. The main reason lies in that learning is a social constructive process (Palincsar, 1998; Li, 2013) in which students' learning process could be best facilitated only if students are guided by teachers in a proper manner. Best learning outcomes cannot be secured without the presence of the teacher.

Other researchers note that the role change from instructor to facilitator in a PBL context cannot happen naturally. Major and Palmer (2006) note that the existing knowledge of the teacher and the intervention from the institute influence the formulation of the facilitators' role to some extent. The teachers who are new to teaching are likely to experience difficulties in acting as PBL facilitators (Spronken-Smith \& Harland, 2009), partly because they are not familiar with the principles and rules of PBL. The role change of teacher is highly dependent on teacher's willingness and ability to make such transformation, institutional support (Young \& Papinczak, 2013), group size, facilitating skills, PBL preparedness (Morales - Mann, \& Kaitell, 2001), social and cultural tradition (Li $\& \mathrm{Du}, 2013)$, and so on. As for PBL teachers, they have to make best use of all resources and opportunities to foster their role change from traditional instructor to good facilitator (Ertmer \& Simons, 2006). Institutes should set development programs so as to assist teachers to alter their role and to grow into more effective PBL facilitators (Hendry, 2009; Salinitri, Wilhelm \& Crabtree, 2015).

\subsection{PBL implementation and teachers' perceptions regarding PBL in China}

PBL has been incorporated into Chinese education system in recent years, and it is adopted as a basic educational approach either for a single course $(\mathrm{Du}, \mathrm{Su} \&$ 
Liu, 2013; Zhan, 2018) or for a program (Li, 2013). A great many Chinese medical institutes employ PBL as a basic education approach, but with limited curriculum hours (Fan et al., 2014). Literature shows that the use of PBL in China is quite promising, since it largely promotes student' learning outcomes such as self-directed learning skills, critical thinking, interdisciplinary learning, communication skills (Du, Su \& Liu, 2013; Zhao, Zhang, \& Du, 2017; Zhan, 2018; $\mathrm{Li}, 2018)$. However, researchers also demonstrate that introducing PBL into Chinese education system can be a challenging task. It could be a source shortage issue, since the number of qualified PBL facilitator is far from being sufficient (Long \& Qin, 2014). However, the most important reason is that there is notable tension between Chinese tradition and the essence of PBL. It is found that many Chinese students conceive learning as knowledge accumulation and passing exams due to the large influence of the exam-oriented education tradition (Kirkpatrick \& Zang, 2011). Chinese students are accustomed to passive learning and conforming to teachers' authority, which undermines PBL implementation to a large extent (Wang et al., 2008). Li and Du (2013) note that traditional teacher-student relationship makes it quite challenging for higher education institutes to develop a student-directed learning model in China.

Chinese teachers are normally expected to act as ethical model, learning model, and parental model for their students. The ethical role implies that respecting and conforming to teacher is widely considered as virtue of student. The learning model means that Chinese teacher is supposed to show student the most efficient and correct way to learn and help student avoid making mistakes. Parental role implies that teacher in China should take full responsibility for students, care after students in and after class, and direct them in both learning and personal development (Zhao, Zhang, \& Du, 2017). Therefore, Chinese students are encouraged to obey their teachers' directions rather than challenge them or develop their own learning approach. Further, PBL encourages giving students more freedom to make their own learning decisions; however, many Chinese teachers are quite reluctant to granting autonomy to students, since they think they are fully responsible for students' learning and should assist students avoid making mistakes ( $\mathrm{Li} \& \mathrm{Du}, 2015)$. It further indicates a dilemma between teachers' intention to stimulate students' self-direct learning and their tendency to maintain directive role in teaching and learning processes ( $\mathrm{Li} \& \mathrm{Du}, 2015)$.

\section{Method}

This study aims at investigating Chinese teachers' conceptions of their roles as PBL facilitator. The PBL teachers from a medical institute which has introduced PBL in recent years in China are selected as research object. Data collection and analysis are conducted mainly in a qualitative manner.

\subsection{Research site}

Empirical study for this paper is conducted at medical School $\mathrm{C}$ in northern China. Traditionally, the educational approach in this medical institute was marked by teacher-dominant teaching, with the aim of equipping students with basic knowledge and clinical skills in medical field. In order to enhance its 
teaching and learning quality and better prepare students for future challenge, School C decided to introduce PBL into its curriculum system so as to transform its teaching and learning method. The teachers were given high autonomy to define what PBL was, how they acted in PBL class and how they facilitated PBL groups. Generally speaking, PBL in this medical institute falls into what is classified as case-based PBL approach, developed by Barrows and Tamblyn (1980). The learning process was organized around addressing a medical case where students worked on a medical problem in the form of groups. The teachers at School $\mathrm{C}$ were expected to make pedagogical changes in accordance with the spirit of PBL and to transform from traditional instructors to facilitators. However, since there was no clear definition of what a facilitator meant at the management level, the teachers from this institute were able to formulate their own conceptions of what a PBL facilitator was and how they should behave in PBL classes.

\subsection{Data collection and analysis}

Since this study is mainly concerned with the conceptions of the Chinese teachers regarding their role within PBL context, qualitative approach is employed for data collection and analysis. Interviews are employed as the primary method for data collection. A list of PBL teachers was provided by the university and the interviewees were randomly chosen from the list. A total of 32 teachers (13 female and 19 male teachers) who participated in PBL teaching and tutoring in the past few years are selected as the interviewees. Of all the 16 departments we have investigated, 2 interviewees from each department have been chosen. Each interview was conducted around 45 minutes. The interviews are taken in a semi-structured manner (Cohen, Manion \& Morrison, 2007) with several open-ended questions such as teachers' background, their understanding of PBL, their understanding of the role as PBL facilitator, and how they conduct PBL in their own courses. All interviews are conducted in Chinese. In addition to interview, observation is conducted as a complementary data source to triangulate the validity of the study from another perspective (Creswell, 2009). We were allowed to enter into the PBL classes of some interviewees and observe how these teachers manage PBL classes, supervise groups, and scaffolding student learning.

After data collection, all interviews are manually transcribed and coded. The comments and quotations are categorized into different themes and translated into English after the completion of several rounds' reviewing. The key words and terms are highlighted in each category and correspond with each teacher's conceptions of their roles in PBL; afterwards new patterns were identified by making a cross-category analysis.

\section{Research findings}

In general, two polarized patterns of the teachers' conceptions of their role as PBL facilitator emerge: around two thirds of the teachers (20 out of 32) insist that teacher should have a dominant role in PBL teaching and learning process and thus maintain higher interference with students' learning process, whereas one third of the PBL teachers (12 out of 32) position PBL facilitator as "outsiders" of student learning who only keep minimum involvement in student learning. 
Table 1. PBL teachers' role types

\begin{tabular}{|l|l|}
\hline \multicolumn{1}{|c|}{ Role type } & \multicolumn{1}{c|}{ Major Characteristics } \\
\hline $\begin{array}{l}\text { Dominator or } \\
\text { director for } \\
\text { students }\end{array}$ & Give student direct and detailed guidance \\
\cline { 2 - 2 } & Keep students right on track \\
\cline { 2 - 2 } & Secure correctness and avoid making mistakes \\
\cline { 2 - 2 } $\begin{array}{l}\text { Outsider of } \\
\text { student' } \\
\text { learning }\end{array}$ & Strong interference with student learning \\
\cline { 2 - 2 } & Give student high learning autonomy \\
\cline { 2 - 2 } & Ollow students making mistakes \\
\cline { 2 - 2 } & Minimum interference with student learning \\
\hline
\end{tabular}

4.1 Teachers' conception of their role as dominator or director

Many teachers are strongly supporting that PBL teacher should play a dominant role in student' learning process. Although they agree that PBL teacher should act as "facilitator" rather than traditional instructor, they interpret the meaning of a facilitator in a "teacher-centered" manner. For these teachers, PBL facilitator is more like dominator or director. For instance, a number of interviewees hold that PBL teachers should give students a direct and detailed guidance. As some interviewees state,

"Chinese students are passive learners and highly relying upon teachers' guidance, generally speaking, Chinese teachers have to direct the learning process and make all arrangement regarding to learning."(Teacher 1)

"Before PBL session, I have to do a lot of work. I have to tell students what $P B L$ is, what they should do, what kind of medical problems we are going to use, what kind of knowledge we are going to mention and apply during PBL group work, how to formulate groups, how to set up basic rules of PBL discussion. There are a lot of detailed things that a PBL teacher should consider." (Teacher 5)

Keeping student learning "right on track" and help student avoid making mistakes are often mentioned by interviewees as PBL teacher's major roles. "On track" can both mean students' learning should be progressed according to the curriculum time schedule, or students should learn the right knowledge and avoid making mistakes. As some teachers comment,

"Teachers should be responsible for student learning. They have to make sure that students' learning process proceeds according to the time table in the curriculum syllabus. They also have to secure the correctness of what students have learned or discussed. " (Teacher 10) 
"As a teacher, you have a lot of responsibilities for the students. Since PBL gives students a lot of freedom, one of the teachers' job to make students learn 'right on track'. Otherwise, the students might do something wrong, or discuss something useless, or irrelevant to the theory knowledge. Therefore, teachers should watch students very carefully, and interrupt students on time as long as they find students doing something that is not right." (Teacher 21)

"Teachers are experts in medical field and they have much more knowledge than students do. They know what is correct and what is wrong. They know how to learn in an efficient way. They should direct students in PBL environment. Since students are immature learners, they should follow their teachers' instructions."(Teacher 3)

"Medical field is very serious, different from any other fields. The line between right and wrong is quite clear. It concerns people's health. Therefore, the mistakes in medical domain should be corrected on time during the learning process." (Teacher 25)

Besides these arguments, a general consensus of the teachers from this category is to maintain strong control over student learning process, as one teacher states,

\begin{abstract}
"PBL does not mean that teacher leave students alone and learn on their own. Rather, it means that teacher have more jobs to do. Teacher does not only have to make preparation for PBL beforehand, but also need to pay attention to student learning during class. You know, you have to concern student a lot when students work on groups. Once they did something wrong or inappropriate, you have to stop them for a while and correct them on time." (Teacher 30)
\end{abstract}

During our observations, we also find that the teachers from this category tend to organize PBL classes in a more teacher-centered manner. For instance, some teachers are always seated in the mid of student groups attempting to host and direct PBL discussion, even though there are student group leaders for each PBL group. When the students are discussing something which is not expected by teacher, the teachers always jump in, pause the students, and revert students' group work in a course according to the teachers' original design.

\title{
4.2 Teachers' conceptions of their role as "outsiders"
}

Around one third of the PBL teachers interviewed in this study hold a different view of their roles from their counterparts from the previous category. In general, the teachers of this category conceive PBL facilitator as "outsiders" of student learning and they are enthusiastic about giving student sufficient autonomy to carry out PBL related activities. As one interviewee comments,

"PBL is a student-centered approach. Therefore you have to give them freedom to make their own decisions and arrange their own learning process. That is the spirit of PBL." (Teacher 6) 
"A student-directed learning approach means that the teachers have to change their roles from traditional instructors who teach students every detail of the medical knowledge content to facilitators to offer support. When it is a PBL class, you have to let the students dominate the learning process, to make their own discoveries and explorations." (Teacher 11)

In PBL classes, teachers seem to be "outsiders" of student learning. The observations of this study notice that the teachers from this category always choose to sit in the corner of the classroom, far from student group. When the students carry out PBL activities or make group discussions, the teachers only serve as "observers" or "recorders" who note down the students' performance. They seldom make interruptions when the students have their PBL discussions. As a teacher recalls,

"My main job is to observe and make records of student performance in the PBL class. It can give me some evidence for me to make assessment of student learning performance. It also includes all errors the students have made in the class, which I would lecture in another session. During the PBL class, normally I don't talk or interrupt students." (Teacher 15)

The PBL teachers belonging to the "dominant" category worry a lot about students making mistakes during their learning process and therefore they attempt to interrupt students in order to minimize the opportunities that the students acquire the wrong knowledge content. On the contrary, the teachers from this category hold a different view on students making mistakes. As an interviewee concludes,

"Of course students might make mistakes in the learning process. But I think teachers do not need to worry too much about it. Making mistakes is quite normal in the whole learning process. Nobody can learn something without making mistakes. ...I don't think teachers should jump in wherever students have a mistake, because that will interrupt the normal learning pace of the students and harm their learning autonomy.... Of course I do make corrections of the students' mistakes, but I only do it at the end of the PBL class instead of jumping in when students are discussing their problems." (Teacher 19)

Compared to "dominant" PBL teachers, the tutors from "outsider" category agree on minimizing their involvement in student' learning, as some interviewees comment,

"In order to protect student learning autonomy and foster student's selfdirected learning skills, I guess it is better for teacher to let students learn on their own. Teacher does not need to intervene with students during PBL work unless it is extremely necessary. " (Teacher 31)

"PBL teachers should give student academic support. There is no doubt about it. However, teachers' should be careful about the time regarding 
when they give students guidance. Teachers should bother students if it is not necessary." (Teacher 23)

\section{Discussion}

This study notices two different conceptions on PBL facilitator's role of Chinese teachers, respectively, dominator or director of student, and outsider of student learning. The majority of the teachers in this study are in favor of a more conservative view on PBL facilitator by supporting giving students direct and detailed guidance, keeping students' learning progress "right on track", securing the correctness of student learning and avoiding making mistakes, and maintain strong interference in students' learning process. A few Chinese teachers advocate giving students high autonomy to learn, teachers serving as outsiders, allowing students making mistakes, and intervening with students learning process at a minimum level. The two conceptions noted from this study share some similarities with the categories developed by Dahlgren, Castensson and Dahlgren (1998) and Mohamad et al. (2009). All three studies on the conceptions of PBL facilitator's role include a more teacher-centered view which highlights the role of the teacher in teaching and learning process, and a student-centered perception, which emphasizes students taking responsibility for learning. However, the conceptions on PBL teacher's role from this study are more polarized, either focusing on teacher or student; an in-between teacher-centered and student-centered conception is not found in this study.

Here, we agree on the notion that PBL is based upon social constructivism (Palincsar, 1998; Li, 2013; Li \& Du, 2018) that learning is socially constructed (Savin-Baden \& Major, 2004; Kolmos, 2008), implying that learning should be a constructive process directed by students themselves (usually referred as selfdirected learning) and be a process of interaction among students, and between students and teachers (Palincsar, 1998; Li \& Du, 2018). Teacher's proper guidance and involvement in student' learning process is an integral part of PBL(Mascolo, 2009). In this sense, too much emphasis on either teacher or student is equally flawed. The conception on PBL facilitator as dominator or director is detrimental to student learning autonomy, and it reverts learning back to a traditional course where learning becomes passive information transmission from teacher to students. It may also harm students' learning motivation and interest since a teacher-centered approach deprives students' sense of ownership of learning. The conception of PBL facilitator as "outsider" seems to be respective of students' learning autonomy; however, it is equally disadvantageous for students, since it may weaken the role of the teacher in students' learning process (Mascolo, 2009). A good PBL facilitator should play an in-between role, balancing elements from different requirement (LybergÅhlander, Lundskog \& Hansson, 2014), always be flexible and contingent, and be able to make adjustment to his/her behavior in response to students' learning context.

Chinese teachers' conceptions on PBL facilitator's role can be interpreted from many different aspects. The dominator/director image of PBL facilitator can be accounted by Chinese teachers' conception of learning as knowledge accumulation, and more importantly, by China's particular education tradition. 
The Confucius educational tradition in China is manifested by teacher-centered education, teacher outlining path for students to follow, teacher not challenged or criticized, and so on (Hofstede, 1986). As Chinese teachers are expected to play several roles in terms of ethical model, learning model, and parental role ( $\mathrm{Li}$ $\& \mathrm{Du}, 2013)$, they are likely to formulate a conception of good teacher, who should take full responsibility for students, including their learning and personal development. Under this cultural tradition, the intention of dominating and directing student is not conventionally considered as a shortcoming of teacher; rather, it is something that a responsible teacher should do and it becomes virtue of good teachers. Nowadays, although this tradition is weakening, it still has a significant impact upon Chinese educational practice. For instance, some Chinese researchers insist on the value of teacher's dominance in teaching and learning process (Shao \& Liao, 2007). In this sense, a good PBL facilitator is often expected to give student detailed instruction and be intolerant with students making errors and detours. Therefore, in order to facilitate the development of a self-directed learning approach such as PBL, a conceptual change regarding the meaning of learning and good teacher is needed to Chinese teachers who hold the conception of PBL facilitator as dominator and director.

In addition to this, the formulation of Chinese teachers' conceptions on the role of PBL facilitator can be understood from a cognitive point of view. Since current PBL teachers have been educated and trained within teacher-centered educational tradition, they relatively lack the knowledge and skill regarding what PBL is and how to facilitate students. The existing knowledge of the teacher influences one's conception on facilitators' role (Major \& Palmer, 2006), therefore, when considering the role of PBL facilitator, Chinese teacher have a tendency to make a choice between two extreme options: either maintaining dominance over student' learning process, as a traditional instructor does, or strongly opposing to teacher-centered tradition by leaving student alone or keeping minimum involvement in PBL activities. Therefore, institutes should offer more support (Mohamad et al., 2009; Young \& Papinczak, 2013; Salinitri, Wilhelm \& Crabtree, 2015) such as faculty develop programs for PBL teachers to obtain more knowledge content regarding what PBL is and what it means by a good facilitator and to develop skills in facilitating PBL groups.

\section{Conclusion}

This study identifies two different types of teachers' conceptions regarding PBL facilitator's role. Many Chinese teachers are holding a conservative view about their roles in PBL classes. They insist that teachers should play a dominant role in students' learning process in terms of giving students direct and detailed guidance, keeping students' learning progress "right on track", securing the correctness of student learning and avoiding making mistakes, and maintain strong interference in students' learning process. A few Chinese teachers advocate giving students high autonomy to learn, teachers serving as outsiders, allowing students making mistakes, and keeping minimum involvement in students' learning process. The polarized conceptions on PBL facilitator's role can be accounted by Chinese particular education tradition, and a lack of 
knowledge in PBL and its facilitating skills. From a social constructivism viewpoint, we agree that PBL teachers should involve in student learning process in a proper manner: they should offer suitable academic support and guidance for students rather than leave students alone since knowledge is socially constructed between students and teachers; however, they should be equally aware that they need to encourage students to develop their selflearning abilities and not hurt students' learning autonomy. In this sense, to foster PBL implementation in Chinese higher education institutes, it calls for a conceptual change to Chinese teachers regarding what learning is and what good PBL teacher or facilitator is. It also requires higher education institutes to set faculty development programs and offer other institutional support so as to equip teachers with more PBL related knowledge content and PBL facilitating skills.

\section{Research limitation and future direction}

This study outlines two different conceptions of Chinese teachers regarding their roles in PBL classes. Nevertheless, the research is largely dependent upon qualitative data rather than quantitative data; the conclusion would be reinforced and generalized to a larger extent if more quantitative research were conducted. Further, how teachers' conceptions influence students' learning behavior and their learning results remains unknown. As some researchers have already noticed PBL's strength in improving Chinese students' learning outcome (Fan et al., 2014; Du, Su \& Liu, 2013; Zhan, 2018), it is quite interesting to ask a series of questions such as: do these two conceptions on PBL facilitator's role equally enhance Chinese students' learning outcome? If not, what kind of PBL teacher can improve what kind of learning result? In this sense, more researches need to be done to examine the relationships among PBL teachers' selfconceptions, their performance in PBL classes, as well as students' learning outcomes.

\section{Reference}

Alrahlah, A. (2016). How effective the problem-based learning (PBL) in dental education. A critical review. The Saudi dental journal, 28(4), 155-161. Retrieved from: https://doi.org/10.1016/j.sdentj.2016.08.003.

Barrett, T., \& Moore, S. (2010). New approaches to problem-based learning: Revitalising your practice in higher education. London: Routledge.

Barrows, H. S., \& Tamblyn, R. M. (1980). Problem-Based Learning: An Approach to Medical Education. New York: Springer.

Boud, D. (1985). Problem-Based Learning in Education for the Professions. Sydney: Higher Education Research and Development Society of Australia.

Bowe, B. (2007). Managing the Change from Traditional Teaching to Problem-based Learning in Physics Education. In A. Kolmos, \& E. de Graaff, (Eds.). Management of Change (pp. 83-91). Rotterdam: Sense Publishers.

Chan, L. (2008). The role of a PBL tutor: a personal perspective. The Kaohsiung Journal of Medical Science, 24(3), S34-S38. Retrieved from: https://doi.org/10.1016/s1607$551 \times(08) 70092-5$. 
Cohen, L., Manion, L., \& Morrison, K. (2007). Research Methods in Education (6th edition). New York: Routledge. Retrieved from: https:// doi.org/10.4324/9780203029053.

Connolly, D., \& Silen, C. (2011). Empowering Tutors: Strategies for Inspired and Effective Facilitations of PBL Learning. In T.Barrett, \& S. Moore (Eds.). New Approaches to Problem-Based Learning: Revitalising Your Practice in Higher Education (pp. 215-227). New York: Routledge.

Creswell, J. (2009). Research Design: Qualitative, Quantitative, and Mixed Methods Approaches. London: Sage.

Dahlgren, M.A., Castensson, R., \& Dahlgren, L.O. (1998). PBL from the teachers' perspective. Higher Education, 36(4), 437-447. Retrieved from: https:// doi.org/10.1023/A:1003467910288

De Graaff, E., \& Kolmos, A.(2003). Characteristics of Problem-based Learning. International Journal of Engineering Education, 19(5), 657-662. Retrieved from: https://www.ijee.ie/articles/Vol19-5/IJEE1450.pdf.

Dolmans, D. H., Gijselaers, W. H., Moust, J. H., Grave, W. S. D., Wolfhagen, I. H., \& Vleuten, C. P. V. D. (2002). Trends in research on the tutor in problem-based learning: conclusions and implications for educational practice and research. Medical teacher, 24(2), 173-180. Retrieved from: https://doi.org/10.1080/01421590220125277.

Dolmans, D. H. J. M., De Grave, W., Wolfhagen, I. H. A. P., \& van der Vleuten, C. P. M. (2005). Problem-based learning: future challenges for educational practice and research. Medical Education, 39(7), 732-741. Retrieved from: https://doi.org/10.1111/j.1365-2929.2005.02205.x.

Donnelly, R. (2013). The role of the PBL tutor within blended academic development. Innovations in Education and Teaching International, 50(2), 133-143. Retrieved from: https://doi.org/10.1080/14703297.2012.760866.

Du, X., Su, L., \& Liu, J. (2013). Developing sustainability curricula using the PBL method in a Chinese context. Journal of Cleaner Production, 61, 80-88. Retrieved from: https://doi.org/10.1016/j.jclepro.2013.01.012.

English, M. C. , \& Kitsantas, A. (2013). Supporting Student Self-Regulated Learning in Problem- and Project-Based Learning. Interdisciplinary Journal of Problem-Based Learning, 7(2), 128-150. Retrieved from: https://doi.org/10.7771/1541-5015.1339.

Ertmer, P. A., \& Simons, K. D. (2006). Jumping the PBL implementation hurdle: Supporting the efforts of K-12 teachers. Interdisciplinary Journal of Problem-based Learning, 1 (1), 40-54. Retrieved from: https://doi.org/10.7771/1541-5015.1005.

Fan, A. P. C., Kosik, R. O., Tsai, T. C. C., Cai, Q., Xu, G. T., Guo, L., ... \& Chen, Q. (2014). A snapshot of the status of problem-based learning (PBL) in Chinese medical schools. Medical teacher, 36(7), 615-620. Retrieved from: https://doi.org/10.3109/0142159X.2014.902045.

Frambach, J. M., Driessen, E. W., Chan, L. C., \& van der Vleuten, C. P. (2012). Rethinking the globalisation of problembased learning: how culture challenges self-directed learning. Medical Education, 46(8), 738-747. Retrieved from: https:// doi.org/10.1111/j.1365-2923.2012.04290.x.

Frambach, J. M., Driessen, E. W., Beh, P., \& van der Vleuten, C. P. (2014). Quiet or questioning? Students' discussion behaviors in student-centered education across cultures. Studies in Higher Education, 39(6), 1001-1021. Retrieved from: https://doi.org/10.1080/03075079.2012.754865. 
Hofstede, G. (1986). Cultural differences in teaching and learning. International Journal of Intercultural Relations, 10(3), 301-320.

Hallinger, P., \& Lu, J. (2011). Implementing problem-based learning in higher education in Asia: challenges, strategies and effect. Journal of Higher Education Policy and Management, 33(3), 267-285. Retrieved from: https:// doi.org/10.1080/1360080X.2011.565000.

Hendry, G.(2009).Problem-based learning tutors' conceptions of their development as tutors. Medical Teacher, 31(2), 145-150. Retrieved from: https://doi.org/10.1080/01421590802146026.

Huang, R. (2005).Chinese International Students' Perceptions of the Problem-Based Learning Experience. The Journal of Hospitality Leisure Sport and Tourism, 4(2), 3643. Retrieved from: https://doi.org/10.3794/johlste.42.108.

Kirkpatrick, R., \& Zang, Y. (2011). The negative influences of exam-oriented education on Chinese high school students: Backwash from classroom to child. Language Testing in Asia, 1(3), 36. Retrieved from: https://doi.org/10.1186/2229-0443-1-336.

Kolmos, A. (2008). Problem-based and Project-based Learning: Iinstitutional and Global Change. In O. Skovsmose, P. Valero, \& O. Christensen, (Eds.). University Science and Mathematics Education in Transition (pp. 261-280). New York: Springer.

Lee, G., Lin, C.,\& Lin, Y. (2012). How experienced tutors facilitate tutorial dynamics in PBL groups. Medical Teacher, 35(2), e935-e942. Retrieved from: https:// doi.org/10.3109/0142159x.2012.714883.

Li, H. (2013). Educational Change towards PBL (Problem Based Learning): An Organizational Perspective. Aalborg: River Publishers.

Li, H. (2018). Facilitating Learning through PBL in a Chinese Context- Students' Learning Outcomes and Attitudes. International Journal of Learning, Teaching and Educational Research, 7(7), 80-93. Retrived from: https:// doi.org/10.26803/ijlter.17.7.5.

Li, H., \& Du, X. (2013). Confronting Cultural Challenges When Restructuring the Teacher-Student Relationship in A Chinese Context. In M. Kirkebæk, X. Du, \& A. Jensen (Eds.), Teaching and Learning Culture: Negotiating the Context (pp. 79-94). Rotterdam: Sense Publisher. Retrieved from: https://doi.org/10.1007/978-946209-440-6_6.

Li, H., \& Du, X. (2015). Teachers' Perspective of their Role and Student Autonomy in the PBL Context in China. International Journal of Learning, Teaching and Educational Research, 10(2), 18-31. Retrieved from: http://www.ijlter.org/index.php/ijlter/article/download/259/103.

Li, H., \& Du, X. (2018). Educational Design for Future: Case Study of the Curriculum Model and Education Idea of Problem Based Learning at Aalborg University in Denmark(面向未来的课程设计：奥尔堡大学 PBL 课程模式与教育理念探析), Chongqing Higher Education Research (重庆高教研究), (3),117-127.

Long, T., \& Qin, D. (2014). Challenges of Conducting Problem-Based Learning in a Large Class. Chinese Education and Society, 47 (3), 106-110. Retrieved from: https://doi.org/10.2753/CED1061-1932470312.

Lyberg-Åhlander, V., Lundskog, M., \& Hansson, K. (2014). Experiencing the role of PBL tutor. Clinical linguistics \& phonetics, 28(1-2), 36-46. Retrieved from: https://doi.org/10.3109/02699206.2013.816371. 
Major, C.H., \& Palmer, B. (2006). Reshaping Teaching and Learning: The Transformation of Faculty Pedagogical Content Knowledge. Higher Education, 51(4), 619-647. Retrieved from: https://doi.org/10.1007/s10734-004-1391-2.

Mascolo, M. (2009). Beyond Student-Centered and Teacher-Centered Pedagogy: Teaching and Learning as Guided Participation. Pedagogy and the Human Sciences, 1(1), 3-27. Retrieved from: http://scholarworks.merrimack.edu/phs/vol1/iss1/6.

Mohamad, N., Suhaimi, F. H., Das, S., Salam, A., Bujang, S. M., Kamarudin, M. A., ... \& Zurinah, W. N. (2009). Problem Based Learning Facilitation: New Challenges to Higher Education Educators. International Medical Journal, 16(4), 243-246. Retrived from: https:/ / web.b.ebscohost.com/abstract?direct=true\&profile=ehost\&scope $=$ site\& authtype $=$ crawler $\&$ jrnl $=13412051 \& A N=45896165 \& \mathrm{~h}=\operatorname{mgTcz} 6 \mathrm{pPS7} \% 2 \mathrm{bszFCHZX}$ dWIXNQmy1OPzDi2shcevbTQEy7OVROOCxUvxq2r9iTbEXwr3VIfcVXEri3i3K MTGYLwg\%3d\%3d\&crl=c\&resultNs=AdminWebAuth\&resultLocal=ErrCrlNot Auth\&crlhashurl=login.aspx\%3fdirect $\% 3$ dtrue $\% 26$ profile\%3dehost $\% 26$ scope $\% 3$ dsite\%26authtype\%3dcrawler\%26jrnl\%3d13412051\%26AN\%3d45896165

Morales - Mann, E. T., \& Kaitell, C. A. (2001). Problem - based learning in a new Canadian curriculum. Journal of advanced nursing, 33(1), 13-19. Retrieved from: https:// doi.org/10.1046/j.1365-2648.2001.01633.x.

Palincsar, A.(1998). Social contructivist perspectives on teaching and learning. Annual Review of Psychology, 49, 345-375. Retrieved from: https://doi.org/10.1146/annurev.psych.49.1.345.

Rotgans J., \& Schmidt, H. (2011). The role of teachers in facilitating situational interest in an active-learning classroom. Teaching and Teacher Education, 27(1), 37-42. Retrieved from: https://doi.org/10.1016/j.tate.2010.06.025.

Salinitri, F. D., Wilhelm, S. M., \& Crabtree, B. L. (2015). Facilitating Facilitators: Enhancing PBL through a Structured Facilitator Development Program. Interdisciplinary Journal of Problem-Based Learning, 9(1), 72-82. Retrieved from: https:// doi.org/10.7771/1541-5015.1509

Savery, J. R. (2006). Overview of Problem-based Learning: Definitions and Distinctions. Interdisciplinary Journal of Problem-Based Learning, 1(1), 9-20. Retrieved from: https:// doi.org/10.7771/1541-5015.1002.

Savin-Baden, M. (2003). Facilitating Problem-based Learning: Illuminating perspectives. The Society for Reseach into Higher Education and Open University Press.

Savin-Baden, M., \& Major, C. (2004). Foundations of Problem Based Learning. Berkshire: McGrawHill Education.

Schmidt, H. G., \& Moust, J. H. C. (2000). Factors affecting small-group learning: A review of the research. In C. E. Hmelo (Ed.), Problem-based learning: A research perspective on learning interactions (pp. 19-52). Mahwah, NJ: Erlbaum.

Shao, X., \& Liao, Q. (2007). What Kind of Teacher-student Relationship We Need Actually (我们究竟需要什么样的师生关系). Educational Theory and Practice (教育 理论与实践)，(4)，47-50.

Spronken-Smith,R., \& Harland, T. (2009). Learning to teach with problem-based learning. Active Learning in Higher Education, 10(2), 138-153. Retrieved from: https://doi.org/10.1177/1469787409104787. 
Stojcevski, A., \& Ozansoy, C. (2009). Problem Based Learning in Electrical and Electronic Engineering Education. In X. Du, E. de Graaff \& A. Kolmos (Eds.). Research on PBL practice in engineering education (pp. 199-213). Rotterdam: Sense Publishers.

Wang, G., Tai B., Huang, C., Bian, Z., Shang, Z., Wang, Q., Song G. (2008). Establishing a Multidisciplinary PBL Curriculum in the School of Stomatology at Wuhan University. International Dental Education, 72(5), 610-615. Retrieved from: http://www.jdentaled.org/content/72/5/610.long.

Yew, E.H.J. \& Yong, J.J.Y. (2014). Student perceptions of facilitators' social congruence, use of expertise and cognitive congruence in problem-based learning. Instructional Science, 42(5), 795-815. Retrieved from: https://doi.org/10.1007/s11251-013-9306-1.

Young, L. \& Papinczak, T. (2013). Strategies for sustaining quality in PBL facilitation for large student cohorts. Advances in Health Sciences Education, 18(4), 825-833. Retrieved from: https://doi.org/10.1007/s10459-012-9387-7.

Zhan, S. (2018). The Application of PBL Model in General Knowledge Courses in Colleges and Universities (PBL 模式在高校通识课程中的应用). Higher Education Exploration (高教探索), (5), 50-55.

Zhao, K., Zhang J., \& Du, X. (2017). Chinese business students' changes in beliefs and strategy use in a constructively aligned PBL course. Teaching in Higher Education, 22(7), 785-804. Retrieved from: https://doi.org/10.1080/13562517.2017.1301908.

(This research is sponsored by the General Project of Education Science Research in Shanghai (上海市教育科学研究一般项目). Funding No. C17092 ) 